\title{
Craniofacial Classification of Normal Newborns in Maiduguri Metropolis, Nigeria
}

\author{
Clasificación Craneafacial de los Recién Nacidos Normales en Maiduguri, Nigeria
}

\author{
S. H. Garba; A. I. Numan \& I. G. Mishara
}

GARBA, S. H.; NUMAN, A. I. \& MISHARA, I. G. Craniofacial classification of normal newborns in Maiduguri Metropolis, Nigeria. Int. J. Morphol., 26(2):407-410, 2008.

SUMMARY: Anthropometric measurements, such as craniofacial forms especially in the first days after birth are important for the assessment of neonatal health status and results obtained from such measurements are used in pediatrics, orofacial surgery and diagnostic comprehension between patient and normal populations. There is no published literature about the types of head and face shapes in the Kanuri and Babur/Bura newborns of Maiduguri metropolis. Hence, this study was undertaken to document the various craniofacial forms of newborns of Maiduguri metropolis. Head length, head width, head circumference, face length, face width, prosopic and cephalic indices were measured in 120 newborns of the Maiduguri metropolis. The mean cephalic index in Kanuri male and female newborns were $70.03 \%$ and $77.15 \%$ respectively while that of the Babur/Bura males and females newborns were $73.60 \%$ and $77.23 \%$, respectively. The mean prosopic index in Kanuri male and female newborns were $83.77 \%$ and $82.84 \%$, respectively, while that of the Babur/Bura males and females newborns were $80.74 \%$ and $81.03 \%$, respectively. On comparison with existing literature the Kanuri males and females are dolicocephalic, Babur/Bura males and females are mesocephalic, while both the Kanuri and Babur/Bura newborns have the hypereuryprosopic type of face shape thus the data obtained from this study can be used as local standards for diagnostic and anthropometric evaluation.

KEY WORDS: Cephalic Index; Prosopic Index; Kanuri; Babur/Bura; Dolicocephalic hypereuryprosopic.

\section{INTRODUCTION}

Anthropometric measurements, especially that of the newborn in the first days after birth is important for the assessment of neonatal health status. An important part of anthropometry is craniofacial measurements for the determination of head and face shapes (Golalipour et al., 2003). Anthropometric parameters apart from providing standards also serve as useful adjuncts to other observations in evaluating intrauterine growth, development and in detecting neonatal health problems. Results obtained from such measurements are used in pediatrics, orofacial surgery and diagnostic comprehension between patient and normal populations (Williams et al., 1989).

Anthropometric studies are mostly conducted with the aim of obtaining the characteristics of ethnic groups inhabiting a particular geographical region, it not only assist in understanding the frequency distribution of human morphologies but also in providing the basis for a comparison among different races (Heidari et al., 2006;
Golalipour et al., 2003, 2005; Golalipour, 2006; Zaidi, 1989; Evereklioglu et al., 2002). On the basis of the above factors, anthropometric studies are conducted on the age, sex and racial/ethnic groups in certain geographical zones (Williams et al.,1995; del Sol, 2005; Shah \& Jadhav, 2004; Golalipour et al., 2003, 2005; Golalipour \& Heidari, 2005). The most important cephalometric dimension are length and width of head that determines cephalic index. Background newborn anthropometric data against, which deviations from normal could be assessed are generally lacking in developing countries. So, the physical measurements of newborn are compared with the standards of other countries. But these standards have some limitations related to differences in nutritional and environmental factors. A Medline search (1960 to 2006) using the search words, cephalic index, ethnic differences, neonates, craniofacial forms, Kanuri and Babur/Bura found no results. Against these background, this study was carried out to determine the normal range of cephalic and 
facial dimensions of normal male and female neonates in the two dominant ethnic groups (Kanuri and Babur/Bura) of Borno state, Nigeria. This will provide a data base of craniofacial measurements that will possibly provide orofacial surgeons a wide range of craniofacial dimensions which are essential in craniofacial reconstruction.

\section{MATERIAL AND METHOD}

Study Design. A cross sectional survey was conducted in Maiduguri Metropolis of Borno State, Nigeria. Maiduguri is a state capital located in the North Eastern Region of Nigeria, a town predominantly occupied by the Kanuri and Babur/Bura ethnic groups. This study was carried out on 120 normal neonates of the Kanuri and Babur/Bura ethnic groups. Each ethnic group was made up of 30 males and 30 females. All newborns were evaluated within 12-24 hours after birth and those delivered by caesarean section or showing any craniofacial deformity were excluded from the study. The newborns used were from the labour wards of hospitals within Maiduguri metropolis.

Anthropometric measurements. The following anatomical landmarks were marked and used in the measurements, glabella $(\mathrm{G})$, inion (I) and euryon (E). The anatomical landmarks were defined as follows (Lobo et al., 2005):

Glabella: A point above the nasal root between the eyebrows and intersected by a mid sagital plane.

Inion: The distal most point placed on the external occipital protuberance in the mid sagital plane.

Euryon: The lateral most point placed on the side of the head.

All the measurements were carried out after careful palpation of the head for anatomical landmarks and measurements were taken to the nearest $1 \mathrm{~mm}$. The head length (Greatest anteroposterior diameter) was measured with the help of a spreading caliper, from glabella to inion. Head breadth was measured as the maximum transverse diameter between two euryon using a spreading caliper. Head circumferences of neonates were determined by placing measuring tape round the head to pass above the ears and eyebrows. The face length was taken as the height between nasion to gnathion, while face breadth was measured as the breadth across the zygomatic bones. Cephalic and Prosopic indices were determined based on standard anatomical description (Williams et al., 1989). Depending upon these indices the types of head and face shapes were classified as given by Williams et al. (1989).
Data Analysis. The data obtained from each newborn was recorded in a special form and data was transferred into a computer and analyzed using Statistical Package for Social Scientist (SPSS 11.0). Results obtained were presented as means \pm SEM and percentages. Cranial index (CI) and prosopic index (PI) were calculated by the following formulae respectively.

$$
\begin{aligned}
& \text { CI }=\frac{\text { Head width } \times 100}{\text { Head length }} \\
& \text { PI }=\frac{\text { Face length } \times 100}{\text { Face width }}
\end{aligned}
$$

\section{RESULTS}

A total of 120 normal neonates were studied out of which 60 were males and 60 were females and the means and SEM of head length, head width, head circumference, face length, face width, prosopic and cephalic indices obtained from the neonates are presented in Table I.

The percentage means of cephalic index in Kanuri male and female neonates were $70.03 \%$ and $77.15 \%$, respectively, while that of the Babur/Bura males and females neonates were $73.60 \%$ and $77.23 \%$ respectively. The dolicocephalic type of head shape was dominant in the Kanuri males (66.7\%) and females (43.3\%), while the mesocephalic type was dominant in the Babur/Bura males $(50 \%)$ and females $(63.3 \%)$. The rare types of head shape observed in this study were the brachycephalic and hyperbracycephalic type being completely absent in the males of both ethnic groups (Table II).

Face shape was classified by the prosopic index and the dominant type was the hypereuryprosopic type, which was dominant in Kanuri males (46.7\%), Babur/Bura males (43\%) and Babur/Bura females (40\%, Table II).

\section{DISCUSSION}

In the present study the mean CI for Kanuri and Babur/Bura males was $70.03 \%$ and $73.60 \%$ respectively while that of the Kanuri and Babur/Bura females was $77.15 \%$ and $77.23 \%$, respectively. According to the standard anatomical classification of Williams et al. (1989) the dolicocephalic head shape was dominant in the Kanuri newborns, while the mesocephalic type was dominant in the Babur/Bura newborns. 
GARBA, S. H.; NUMAN, A. I. \& MISHARA, I. G. Craniofacial classification of normal newborns in Maiduguri Metropolis, Nigeria. Int. J. Morphol., 26(2):407-410, 2008.

Table I. Various parameters measured of head and face in Kanuri and Babur/Bura newborns. Results are presented as Means \pm SEM.

\begin{tabular}{lllll}
\hline Parameters Measured & \multicolumn{2}{c}{ Males $(\mathbf{n = 3 0})$} & \multicolumn{2}{c}{ Females $(\mathbf{n}=30)$} \\
\cline { 2 - 5 } & \multicolumn{1}{c}{ Kanuri } & Babur/Bura & Kanuri & Babur/Bura \\
\hline Head length $(\mathrm{cm})$ & $12.38 \pm 0.14$ & $12.12 \pm 0.14$ & $11.64 \pm 0.11$ & $11.55 \pm 0.09$ \\
Head width $(\mathrm{cm})$ & $08.67 \pm 0.12$ & $08.92 \pm 0.07$ & $08.98 \pm 0.06$ & $08.92 \pm 0.05$ \\
Face length $(\mathrm{cm})$ & $06.14 \pm 0.13$ & $05.87 \pm 0.09$ & $05.89 \pm 0.08$ & $05.81 \pm 0.07$ \\
Face width (cm) & $07.33 \pm 0.11$ & $07.27 \pm 0.12$ & $07.11 \pm 0.08$ & $07.17 \pm 0.09$ \\
Head circumference (cm) & $35.50 \pm 0.30$ & $35.30 \pm 0.33$ & $34.91 \pm 0.30$ & $34.55 \pm 0.28$ \\
Cephalic index (\%) & 70.03 & 73.60 & 77.15 & 77.23 \\
Prosopic index (\%) & 83.77 & 80.74 & 82.84 & 81.03 \\
\hline
\end{tabular}

Table II. Distribution of head and face shapes in Kanuri and Babur/Bura newborns. Results are presented as Means \pm SEM.

\begin{tabular}{|c|c|c|c|c|c|c|}
\hline \multirow{3}{*}{ Parameters } & \multirow{3}{*}{ Range(s) } & & \multicolumn{2}{|c|}{ Males $(n=30)$} & \multicolumn{2}{|c|}{ Females $(n=30)$} \\
\hline & & & & & & \\
\hline & & & n $(\%)$ & n $(\%)$ & n $(\%)$ & n $(\%)$ \\
\hline \multirow{3}{*}{ Head shapes } & Dolicocephalic & $<74.9$ & $20(66.7)$ & $15(50)$ & $13(43.3)$ & $8(26.7)$ \\
\hline & Mesocephalic & $75-79.9$ & $10(33.3)$ & $15(50)$ & $12(40)$ & $19(63.3)$ \\
\hline & Brachycephalic & $80-84.9$ & $0(0)$ & $0(0)$ & $2(6.7)$ & $2(6.7)$ \\
\hline \multirow{6}{*}{ Face shapes } & Hyperbracycephalic & $85-89.9$ & $0(0)$ & $0(0)$ & $3(10)$ & $1(3.3)$ \\
\hline & Hypereury prosopic & $<79.9$ & $14(46.7)$ & $13(43)$ & $8(26.7)$ & $12(40)$ \\
\hline & Euriprosopic & $80-84.9$ & $8(26.7)$ & $10(33.3)$ & $8(26.7)$ & $9(30)$ \\
\hline & Mesoprosopic & $85-89.9$ & $1(3.3)$ & $4(13.3)$ & $8(26.7)$ & $7(23.3)$ \\
\hline & Leptoprosopic & $90-94.9$ & $1(3.3)$ & $2(6.7)$ & $4(13.3)$ & $1(3.3)$ \\
\hline & Hyperleptoprosopic & $>95$ & $6(20)$ & $1(3.3)$ & $2(6.7)$ & $1(3.3)$ \\
\hline
\end{tabular}

Since Maiduguri lies in the tropical zone, the classification of the Kanuri newborns as dolicocephalic agrees with a study carried out by Bharati et al. (2001), which concludes that head form is longer (dolicocephalic) in tropical zones. The result also agrees with the study carried out in India (Tuli et al., 1995), but disagrees with the result obtained in this study that showed the Babur/ Bura newborns though living in tropical Nigeria as mesocephalic.

In respect to the variation of head shape in various races and geographical zones, hereditary factors primarily affects the shape of head, however environment also place a secondary effect (Golalipour et al., 2003) .

The obtained prosopic indices showed that the hypereuryprosopic type of face shape was dominant in Kanuri males (46.7\%), Babur/Bura males (43\%) and Babur/ Bura females (40\%), this results agrees with the findings of Mibodi \& Frahani (1996) and Golalipour et al., 2003. Thus the craniofacial variation existing between these ethnic groups might be attributed to genetic and environmental influences (Susanne \& Sharma, 1978) and also food habits (Kasai et al., 1993). The results of the present study showed that the Kanuri males and females are dolicocephalic and Babur/Bura males and females are mesocephalic, while both the Kanuri and Babur/Bura newborns have the hypereuryprosopic type of face shape. But a larger sample size is recommended in further studies.

\section{ACKNOWLEDGEMENTS:}

We are grateful to Dr. Joseph Jatau, Chief Medical Director Hospitals Management Board Borno State Nigeria for his assistance and the Newborns Ward of the University of Maiduguri Teaching Hospital Maiduguri. 
GARBA, S. H.; NUMAN, A. I. \& MISHARA, I. G. Clasificación craneaofacial de los recién nacidos normales en Maiduguri, Nigeria. Int. J. Morphol., 26(2):407-410, 2008.

RESUMEN: Las medidas antropométricas, tales como las formas craneofaciales especialmente en los primeros días después del nacimiento, son importantes para la evaluación del estado de salud neonatal y los resultados obtenidos a partir de estas mediciones se utilizan en pediatría, cirugía orofacial y la comprensión diagnóstica entre el paciente y la población normal. No hay literatura publicada sobre los tipos de formas de cabeza y rostro en los los Kanuri y Babur/Bura recién nacidos de Maiduguri. Este estudio se llevó a cabo para documentar las diversas formas craneofaciales de los recién nacidos de Maiduguri. Fueron medidos la longitud, ancho y circunferencia de la cabeza, altura facial, ancho de la cara, índice prosopo y cefálico en 120 recién nacidos de Maiduguri. La media del índice cefálico en hombres y mujeres Kanuri recién nacidos fueron 70,03\% y 77,15\%, respectivamente; mientras que la de hombres y mujeres Babur / Bura recién nacidos fueron de 73,60\% y 77,23\% respectivamente. La media del índice prosop en hombres y mujeres kanuri recién nacidos fueron $83,77 \%$ y $82,84 \%$, respectivamente, mientras que la de la hombres y mujeres Babur / Bura recién nacidos fueron $80,74 \%$ y $81,03 \%$, respectivamente. En comparación con la literatura existente, los hombres y mujeres Kanuri son dolicocéfalos, hombres y mujeres Babur / Bura son mesocéfalos, mientras que los hombres y mujeres Kanuri y Babur / Bura recién nacidos tienen tienen la cara hipereuriprosopo. Los datos obtenidos de este estudio pueden ser utilizados como las normas locales para el diagnóstico y evaluación antropométrica.

\section{PALABRAS CLAVE: Índice cefálico; Ïndice prosopo: Kanuri; Babur / Bura; Dolicocefálico hipereuriprosopo.}

\section{REFERENCES}

Bharati, S.; Som, S.; Bharati, P. \& Vasulu, T. S. Climated and head form in India. Am. J. Hum. Biol., 13(5):626-34, 2001.

del Sol, M. Cephalic index in a group of mapuche individuals in the IX Región of Chile. Int. J. Morphol., 25:241-6, 2005.

Evereklioglu, C.; Doganay, S.; Er, H.; Gunduz, A.; Tercan, M.; Balat, A. \& Cumurcu, T. Craniofacial anthropometry in a Turkish population. Cleft. Palate Craniofac. J., 59:208-18, 2002.

Golalipour, M. J. The variation of head shapes in 17-20 years old native Fars male in Gorgan-North of Iran. Int. J. Morphol, 24:187-90, 2006.

Golalipour, M. J. \& Haidari, K. Effect of the ethnic factor on cranial capacity and brain weight of male newborns in Northern Iran. Neuroembryology and Aging, 5:146-8, 2005.

Golalipour. M. J.; Haidari, K.; Jahanshahi, M. \& Farahani, R. M. The shapes of head and face in normal male newborns in SouthEast of Caspian Sea (Iran-Gorgan). J. Anat. Soc. India, 52:2831, 2003.

Golalipour, M. J.; Jahanshahi, M. \& Haidari, K. The variation of head and face shapes in female newborns in the South-East of the Caspian Sea (Iran-Gorgan). Eur. J. Anat., 9:95-8, 2005.

Heidari, Z.; Mahmoudzadeh Sagheb, H. R. \& Noori Mugahi, M. H. Morphological evaluation of head and face in 18-25 years old women in southeast of Iran. Med. Sci., 6:400-4, 2006.

Kasai, K.; Richards, L. C. \& Brown, T. Comparative study of craniofacial morphology in Japanese and Australian aboriginal population. Hum. Biol., 65(5):821-31, 1993.

Lobo, S. W.; Chandrashekhar, T. S. \& Kumar, S. Cephalic index of Garung Community of Nepal- An anthropometric study. Kathmandu Univ. Med. J. (KUMJ), 3(3):263-5, 2005.

Mibodi, I. M. A. \& Frahani, M. R. Study of normal range of anatomical dimensions of one-day old newborn by cephalometry. J. Med. Council Islamic Republic of Iran, 14:1-8, 1996.

Shah, G. V. \& Jadhav, H. R. The study of cephalic in students of Gujarat. Anat. Soc. India, 55:25-6, 2004.

Susanne, C. \& Sharma, P. D. Multivariate analysis of head measurements in Punjabi families. Ann. Hum. Biol., 5(2):17983, 1978.

Tuli, A.; Choudhry, R.; Agarwal, S.; Anand, C. \& Gary, H. Correlation between craniofacial dimensions and foetal age. J. Anat. Soc. India, 44:1-12, 1995.

Williams, P. L.; Dyson, M.; Dussak, J. E.; Bannister, L. H; Berry, M. M.; Collins, P. \& Ferguson, M. W. J. Gray's Anatomy. $38^{\text {th }}$ ed. Churchill Livingston, London, 1995. pp.607-12.

Williams, P. L.; Warwick, R.; Dyson, M. \& Bannister, L. H. In: Cranium sexual and racial differences. Gray's Anatomy. $37^{\text {th }} \mathrm{Ed}$. Churchill Livingstone, United Kingdom, 1989. pp.396-7.

Zaidi, S. H. Anthropological study of the mastoid air cell system in Pakistani races. Laryngol. Otol., 103:819-22, 1989.

Correspondence to:

Sani Hyedima Garba

Department of Human Anatomy

College of Medical Sciences

University of Maiduguri, PMB 1069 ,

Borno state - NIGERIA

Email: saniwakawa@yahoo.co.uk
Received: 08-10-2007 Accepted: 21-11-2007 